\title{
VII. Agenda, or a collection of observations and researches the results of which may serve as the foundation for a theory of the earth
}

\section{De Saussure}

To cite this article: M. De Saussure (1799) VII. Agenda, or a collection of observations and researches the results of which may serve as the foundation for a theory of the earth, Philosophical Magazine Series 1, 4:15, 259-265, DOI: 10.1080/14786449908677069

To link to this article: http://dx.doi.org/10.1080/14786449908677069

曲 Published online: 18 May 2009.

Submit your article to this journal $\pi$

Џll Article views: 4

Q View related articles $\sqsubset$ 
Hints for the Formetion of a Tbeory of ibe Eartb:

fail to be of effential fervice to him. This fact I can atteft from experience.

If abfolite precifion be wanted, it may be obtained by employing three or more pyrometers, diftributed at regular diftances rourid the furnace, inftead of ufing only one. The inean of the whole will be the true degree of heat in the furnace.

VII. Agenda, or a Collecion of Obfervations and Refearcbes the Refults of whicb niay ferve as the Foundation for Theory of the Earth. By M. DE SAUSSUnt.

[Continued from page igo.]

CHAP. XVIII.

A. Obfervations to be made on Volcanoes at the Time of ant Etruption.

1. 1 HE form, dimenfions, and elevation of the crater.

*. The colour, elevation, and other fenfible qualities of the flames and the fmoke.

3. Plenomena which preceded the eruption, fubterranean noife, earthquakes, extraordinary thovements of the fea.

4. Phenomena which accompany the eruption; as thunder, lightning, pofitive or negative electricity, fubterranean noife, earthquakes : fcorix, afhes, and itones thrown up; to what height and diftance:

5. Smell of the fmoke. In general it indicates the fulphureous acid; but it may indicate allo bitumen and coal.

6. Nature of the gafes which efcape during the eruption.

7. Velocity of the lava. Its degree of fluidity compared with the inclination of the ground over which it flows.

8. To meafure, if poffible, the degree of its heat when it iffues from the volcano.

9. Whether the lava appears to be in a ftate of comburtion, or only incandefcence. 
IO. Whether it does not cool more flowly, and according. to other laws, than that of the bodies heated or melted in our furnaces.

IO. A. Can it be fuppofed that the matter thrown up by volcanoes was not inflamed, or even in a fate of incandefcence, in the bowels of the earth; and that it is only the contact of the air which gives it thefe qualities ?

Ir. Whether the fudden cooling of lava in the air or in water divides it into prifmatic columns, fuch as thofe of bafaltes.

12. Whether it be true that fcoria newly thrown up, and fuddenly cooled by its rapid paffage through the air, feems covered with a bituminous varnifh.

I3. And, in general, whether the mountain throws up bituminous matter or any thing that refembles the refiduum of the combuftion of coal, or whether it rather throws up pyrites or the refidum of their decompofition.

14. To afcertain by obfervations, and even by experiments, whether it may not be poffible that pyrites or other ferruginous matters decompofed by water, undergo a fermentation, which, acting on grand mafles, may difengage a fufficient heat to produce the effects of a volcano.

15. Or whether, as M. Romme thinks, the fire of volcanoes is kept up by matters accumulated by rivers and currents of the fea.

16. To fearch for means of afcertaining the depth of the focus of the volcano.

17. To examine whether, at the moment when an eruption begins to take place, there is any remarkable change in the tides, currents, fprings, and the neareft fpiracles and volcanoes.

18. Muddy eruptions : their height, bulk, nature of the water they contain; whether it be faline: nature of the earth and ftones thrown up; whether it contains fea fhells, of what kinds, and in what ftate. Watery eruptions: the fame re- 
farches: whether they hold in folution earths not ufually Soluble in water *.

B. Obfervations to be made at all Times on Volcanoes decidedly fucb.

19. Nature of the countries and mountains between which they are found.

20. Hiftory of the volcano: its form, height, and extent in the moft ancient times; its fucceffive changes down to the prefent moment; its lateral mouths, and the epochs of their formation.

21. Chronology and enumeration of its different eruptions; defcription of them, and their moft remarkable characters.

22. To defcend, if poffible, into the craters of extinguifhed volcanoes; to meafure their depth; defcribe their form, the nature of their fides, their ftrata, and the concretions adhering to them, fuch as fulphur, falt, \&c.

22. A. To obferve the fumaroles, or jets of fmoke, often acid, which arife; their temperature, their nature, and their effects on the lava with which they come in contact.

23. To examine the fiffures; whether they contain metallic or ftoney cryftallifations, which may be confidered as fublimed, and formed by the cryftallifation of fubftances reduced to the ftate of fnoke or vapour.

24. The nature of the ftreams of cooled lava; their extent and thicknefs.

25. Whether it be true that, in general, they are porous both at the upper and lower furfaces of the ftrata, and compact in the interior part.

26. To ftudy the nature of the different currents placed above each other, in order to afcertain the difference that may have taken place in the focus of the volcano, and even in the fource of its lava.

- Ta obferve thofe excavations from which confiderable currents of air iffue either neriodically or conftantly. C. 
27. To examine, in gencral, in the lava, the nature of the earth and frones of which it has been formed.

27. A. To fudy the origin of the cryals found inclofed in the lava, as the white garnets or leucites in that of Vefuvius, in order to afcertain whether thefe cryftals have been formed in the lava funce the time of its fufiok, or whether they pre-exilted in the fiones from which the lava was produced.

28. The nature and progrefs of the dacompofition of the different kinds of lava, cither by volcanic acids or meteors.

28. A. Whether there are any which have actually been in fufion, and yct have preferved all the externai characters which the ftone had before it was fubjected to the action of the fubterranean fires:

29. The arigin of volcanic afhes, pozzolanas, tarras, tufas, \&c.

30. The origin of pumice-ftones: whether they are granitcs or feld-fpars, abofites, phrenics, deodalites, or potter's clay more or lels ferruginous, or, lifily, the remains of the decompofition of pit-coal.

30. A. Whether, as M. de Ficlitel belicves, the action of the fire of volcanoes inay augment the fufibility of feldfpar, and change it, in the fame manner as quartz; into real zeolite.

3I. Nature of the obfidians or volcanic glafs: whether they be really glas, and the relults of a complete fution; or whether they are not rather ftones of a vitreous appearance, and which have not becn expofed to the action of a heat fufficiently frong to fufe them.

32. Whether there exif ancient kinds of lava, which, as related of thofe of Ifchia, ace fufceptible of being heated by the moifture of rain and fogs, which wotild fupport the conjecture of No. 14 .

C. Obfervations to be mate on Hills and Mountains which. are doubted to bave becn really Volcanoes.

33. The form, clevation, and other dimenfions of the hill 
or mountain, the volcanic origin of which may appear doubtful,

34. Situation of its frata. To afcend to the fummit of thofe which are inclined; to examine whether they have not a crater, or veftiges of one.

35. To obferve, above all, whether, in departing from the moft elevated point, there are found ftrata diverging in all parts, and proceeding from that point as a centre.

36. To ftudy the characiers of the ftones which have been expofed to the action of the fire, in order to difinguifin them from other porous ftones, fuch as glandulons ftones or amygdaloides.

37. When thefe characters are difcovered, to examine whether, in the neighbourhood of the doubtful mountain, there are found fattered ftones which exhibit the fame characters, and which feem to have proceeded from that moun. tain.

38. To obferve whether there are found, in the neighbourhood of the donbtful mountain, any veftige of the remains of heat concealed in the bofom of the earth, as of thermal, or even acidulous waters. It is well known that thefe figns are equivocal, but their combination with others may throw fome weight into the fcale.

38 . A. Whether there exift certain proofs of alternate depofits of lava or other volcanic productions, and of matters accumulated or depofited by the fea.

39. Among the ftones changed by the fire, to difcover thofe which may be confidered as having been fubjected to the action of one ftratum of coal in deflagration, and which the celebrated Werner calls pjeudo-volcanic, and to diftinguifh them from thofe which have been fufed in a real voleano,

40. Bafaltes: their forms in columns, in beds, round maffes; their connections, the relation which the bafaltes of thefe different forms obferve with each other.

4I. The nature of thele bafaltes: that of their texture, of the points which they contain, of the pores and empty 
264 Hints for the Formation of a Theory of the Earth.

or full cells that maýbe obferved in them; of their different accidents and decompofition.

4x. A. The plenomena they exhibit in the fire, either expofed to, or theltered from the action of the air. But before any arguments are drawn from thefe experiments, it will be neceffary to refolve the queftion, Whether it be true that a ftone may have been melted by fubterrancan fire, and yet none of its characters exhibit thofe indications of fufion which the fire of our furnaces would have given to the fame ftone.

42. Their conncction, if there be any, with lava, fully afcertained as fuch: if it be true, for example, as M. Faujas affirms, that currents of lava are feen terminated by columns of bafaltes.

43. The nature of the bafes on which the bafaltes refts; whether, as M. Werner fays, any is found refting on wacke or hornftone, of an earthy and compact fracture, which itfelf repofes on fand or freeftone.

44. Whether at other times bafaltes is fecn to repole on bods of coal (bouilli) which prefent no indications of combufition.

45. In a word, to examine whether the foil which bears them, or the fides of the veins in which they are contained, prefent indications of the action of fire, or at leaft of having been expofed to the contact of an incandefcent mafs; or, on the contrary, whether there appear indications of depofits of a fubftance which had been in a ftate of aqueous fluidity.

46. Whether there are in the bafaltes veltiges of organifed marine bodies or others; and in what ftate thefe veftiges are found.

47. Whether there are obferved, as MI. Faujas fays, bafaltes which feems to have formed a paffage for itfelf from top to botton through malles of granite.

48. In doubtful cafes of this kind it would be neceffary, werc it poffible to be at the expence, to pun a gallery under a rock of bafaltes, to cxamine whether the columns defcend 
below the foil which feems to carry them; and if they are found below the foil, to fink a vertical well to afcertain the truth of the fyftems which fuppofe them to have been raifed from the interior parts of the earth through the upper ftrata.

[To be concinued.]

VIII. Obfervations on the different Inducements to the Eating of Human Fleßb. By J. DE LovRerro*.

\section{$\mathrm{T}$}

$\mathrm{HE}$ firft inducement which can lead men to this excefs is extreme hunger; but however pardonable it may be under fuch circumftances, if the flefh ufed be that of dead bodies, it is highly deteiftable on account of the confequences. During a dreadful famine in India, which deftroyed more than a hundred thoufand perfons, when the roads and ftreets were covered with dead bodies, becaufe people had not fufficient ftrength to inter them, I faw feveral, have the refolution to preferve their lives by this difgufting food; but fome of them, though not many, found it fo delicious that when the famine was at an end they retained fuch an irrefiftible propenfity to human flefh that they lay in wait for the living in order to devour them. Befides others, there was a mountaineer who concealed himfelf in a foreft near the highway, where he ufed to caft a rope, with a noofe, over the heads of the paffengers, whom he afterwards cut to pieces to gratify his unnatural appetite. He had killed many perfons in this manner, but he was at length caught and executed. At the fame time, and owing to the fame caufe, a woman ufed to go out for the exprefs purpofe of carrying away children who had frayed from their homes. She ftopped up their nofe

* The author of this paper is an eminent Portugruefe naturalif. A copy of it was given by the author from his own manufript, never pubIifhed, to Dr. G. H. Langidorf, phyfician to Prince Chriftian of Waldeck Litibon, on the $5^{\text {th }}$ of January 1798 , who tranllated it into German, and fent it to Profeffor Voigt of Jena. See his Magazin für den nucflen zuf send ser Naturiunde, Vol. I. part 3. 